Provided for non-commercial research and education use. Not for reproduction, distribution or commercial use.

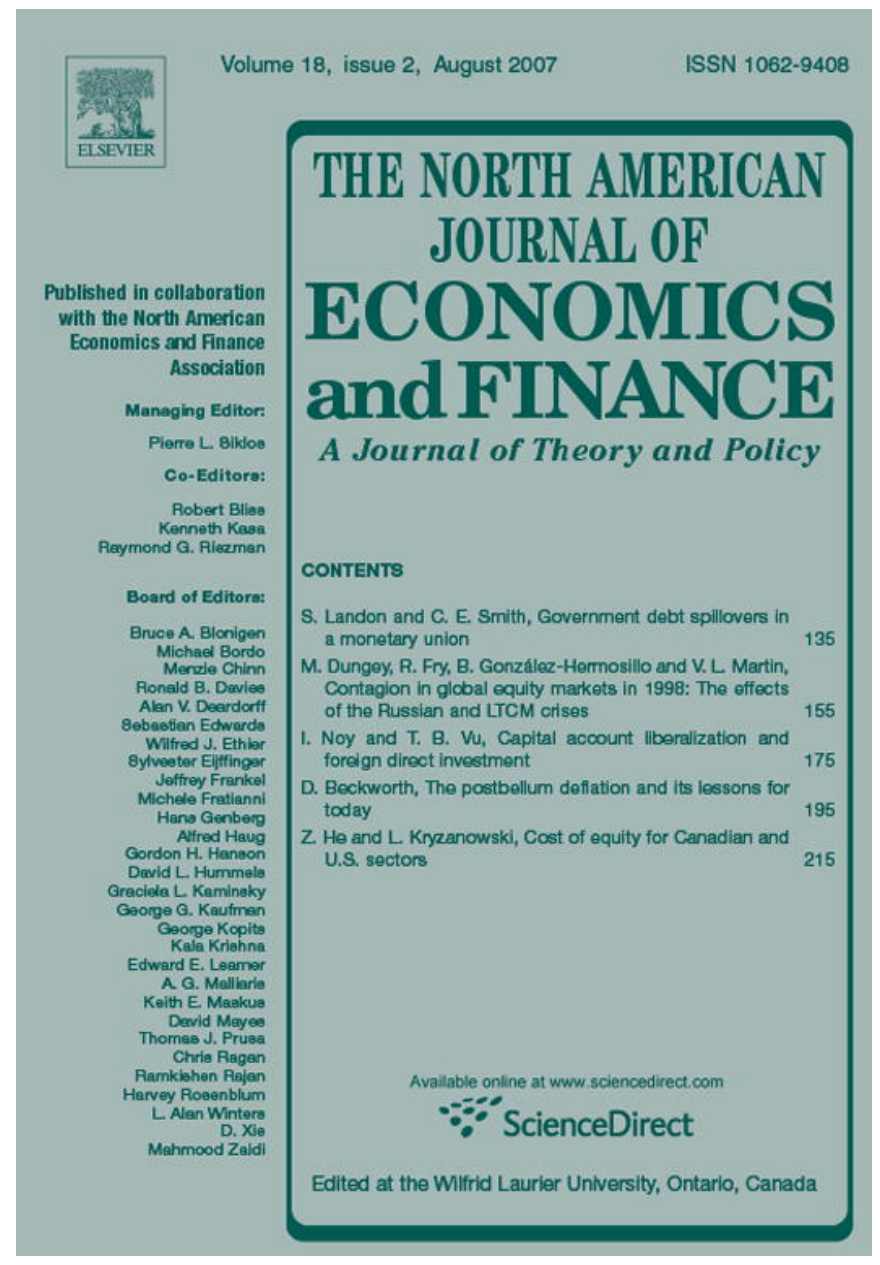

This article was published in an Elsevier journal. The attached copy

is furnished to the author for non-commercial research and education use, including for instruction at the author's institution, sharing with colleagues and providing to institution administration.

Other uses, including reproduction and distribution, or selling or licensing copies, or posting to personal, institutional or third party websites are prohibited.

In most cases authors are permitted to post their version of the article (e.g. in Word or Tex form) to their personal website or institutional repository. Authors requiring further information regarding Elsevier's archiving and manuscript policies are encouraged to visit: 


\title{
Capital account liberalization and foreign direct investment
}

\author{
Ilan Noy ${ }^{\mathrm{a}, *}$, Tam B. Vu ${ }^{\mathrm{b}}$ \\ ${ }^{a}$ Department of Economics, University of Hawaii-Manoa, 2424 Maile Way (Saunders 542), \\ Honolulu, HI 96822, United States \\ ${ }^{\mathrm{b}}$ College of Business \& Economics, University of Hawaii-Hilo, 200 West Kawili Street, \\ Hilo, HI 96720, United States
}

Available online 6 April 2007

\begin{abstract}
We examine the impact of capital account policies on FDI inflows. Using an annual panel dataset of 83 developing and developed countries for 1984-2000, we find that capital account openness is positively but only very moderately associated with the amount of FDI inflows after controlling for other macroeconomic and institutional measures. To a large extent, other country characteristics seem to determine FDI inflows instead of capital account policies. We also find that capital controls are easily circumvented in corrupt and politically unstable regimes. We conclude that liberalizing the capital account is not sufficient to generate increases in inflows unless it is accompanied by a lower level of corruption or a decrease in political risk. (C) 2007 Elsevier Inc. All rights reserved.
\end{abstract}

JEL classification: F21; F36

Keywords: Foreign direct investment; Capital controls; Capital flows; Capital account liberalization

\section{Introduction}

During the past thirty years, foreign direct investment (FDI) has grown in importance with a large number of developing countries able to attract inward FDI in increasing volumes. The theoretical literature that examines FDI identifies a number of channels through which FDI inflows will be beneficial to the receiving economy. ${ }^{1}$ Yet, the empirical literature has lagged behind and

\footnotetext{
* Corresponding author. Tel.: +1 808956 7749; fax: +1 8089564347.

E-mail addresses: noy@ hawaii.edu (I. Noy), tamv@ hawaii.edu (T.B. Vu).

${ }^{1}$ For a recent theoretical contribution, with a discussion of its empirical applicability, see Chakrabarti (2003).
} 
has had more trouble identifying these advantages in practice. Most prominently, a large number of applied papers have looked at the FDI-growth nexus. ${ }^{2}$

The consensus that is slowly emerging is that FDI is beneficial when compared to other types of capital inflows such as portfolio investment or syndicated bank loans, though some maintain that even this beneficial effect is limited. ${ }^{3}$ Additional research efforts are devoted to identifying other features unique to FDI, such as its relative permanence or the positive externalities it generates. ${ }^{4}$ Notwithstanding these fragile conclusions, most countries continue to vigorously pursue policies aimed at encouraging more FDI inflows; these include very significant tax breaks and other types of subsidies granted to multinationals in return for setting up domestic operations. ${ }^{5}$ The multilateral public organizations, in particular the Organization for Economic Cooperation and Development (OECD), the World Trade Organization (WTO) and the International Monetary Fund (IMF), have also been vocal supporters of FDI promotion policies. One of the more common policies international institutions frequently prescribe within this context is liberalization of the capital account. $^{6}$

Yet, very little empirical work has been done to examine the impact of capital account policies on FDI inflows. While neo-classical modeling suggests that capital account liberalization will increase FDI inflows, this might not be the case if the neo-classical assumptions of perfect information, a complete menu of contingent contracts, and competitive markets are relaxed. Developing countries, with their underdeveloped financial markets, lack of corporate transparency, insufficient national data-collection and dissemination, and susceptibility to large fluctuations in exchange rates - might be particularly vulnerable to perverse effects stemming from capital account liberalizations. In this paper, we aim to examine macroeconomic data to investigate the relationship between capital account policies and the inflows of foreign direct investment.

Table 1 presents recent trends in FDI inflows both as a percentage of output and as a percentage of fixed capital formation. Apparent is the worldwide trend increase in the importance of FDI (using both measures) in all geographical regions throughout the 1980s and 1990s, with FDI inflows after 2000 increasing to 4-5 times the level experienced during the 1980s. Yet, in several regions, net FDI flows peaked in the 1995-1999 period, and current levels are still below that peak. For emerging markets Fig. 1 shows that, while 2001-2003 have indeed been years of decline, FDI flows into this group have soared again in 2004 and were predicted to continue soaring through 2006. Their level today is appreciably higher than during the previous peak in $2001 .^{7}$ If these trends continue, an understanding of the determinants of foreign direct investment flows then only become still more important.

\footnotetext{
${ }^{2}$ While most papers identify FDI as a source of technological diffusion, productivity increases, and growth accelerations, the real significance of these effects is still in debate with a minority of papers disagreeing with all these positive conclusions. A prominent contribution, Borensztein et al. (1998), argues that FDI will lead to increased GDP growth only beyond a threshold level of accumulated human capital stock. With the availability of better data, the last few years have seen an especially large number of empirical papers devoted to this question (e.g., Alfaro et al., 2004; Durham, 2004; Hsiao \& Shen, 2003; Li \& Liu, 2005, Vu et al., 2007).

3 Gray (2004) even goes so far as to suggest that countries should restrict FDI inflows, but his position is clearly in the minority among academic economists writing in English.

${ }^{4}$ For widely-cited examples, see Aitken and Harrison (1999), Fernández-Arias and Hausmann (2001), and Sarno and Taylor (1999).

${ }^{5}$ For a critical look at these domestic tax/subsidy policies, see Hanson (2001). For a discussion of the empirical evidence on tax policy's impact on FDI inflows see Hines (1996); and for a more recent survey, Mooij and Ederveen (2003). Gastanaga et al. (1998) analyze other host-country policies that aim to encourage FDI inflows.

${ }^{6}$ For the IMF's role in promoting capital account liberalization, see Joyce and Noy (2005).

7 Mody (2004) offers more analysis of FDI flows over time and across regional groupings.
} 
Table 1

World distribution of FDI

\begin{tabular}{|c|c|c|c|c|c|c|c|c|}
\hline & \multicolumn{4}{|c|}{ FDI net inflows (\% of GDP) } & \multicolumn{4}{|c|}{ FDI net inflows ( $\%$ of fixed capital formation) } \\
\hline & $1980-1989$ & $1990-1994$ & 1995-1999 & $2000-2003$ & $1980-1989$ & 1990-1994 & 1995-1999 & $2000-2003$ \\
\hline World & 1.12 & 2.00 & 3.97 & 5.05 & 4.60 & 8.86 & 15.33 & 24.72 \\
\hline East Asia & 2.61 & 4.60 & 6.10 & 5.26 & 10.28 & 19.05 & 22.66 & 20.84 \\
\hline South-East Asia & 2.70 & 4.19 & 5.51 & 3.27 & 7.88 & 16.35 & 21.22 & 12.75 \\
\hline Latin America & 0.75 & 2.21 & 4.12 & 3.64 & 3.31 & 9.36 & 18.19 & 17.80 \\
\hline Africa & 0.76 & 1.19 & 4.61 & 2.87 & 3.56 & 6.64 & 13.64 & 14.33 \\
\hline Middle East and North Africa & 0.73 & 1.23 & 0.74 & 1.62 & 2.80 & 5.61 & 3.35 & 7.53 \\
\hline Other & 1.21 & 1.26 & 3.66 & 4.64 & 4.53 & 6.84 & 16.58 & 19.64 \\
\hline
\end{tabular}

Data is taken from the World Bank's World Development Indicators 2004: BX.KLT.DINV.DT.GD.ZS and BX.KLT.DINV.DT.GI.ZS. 


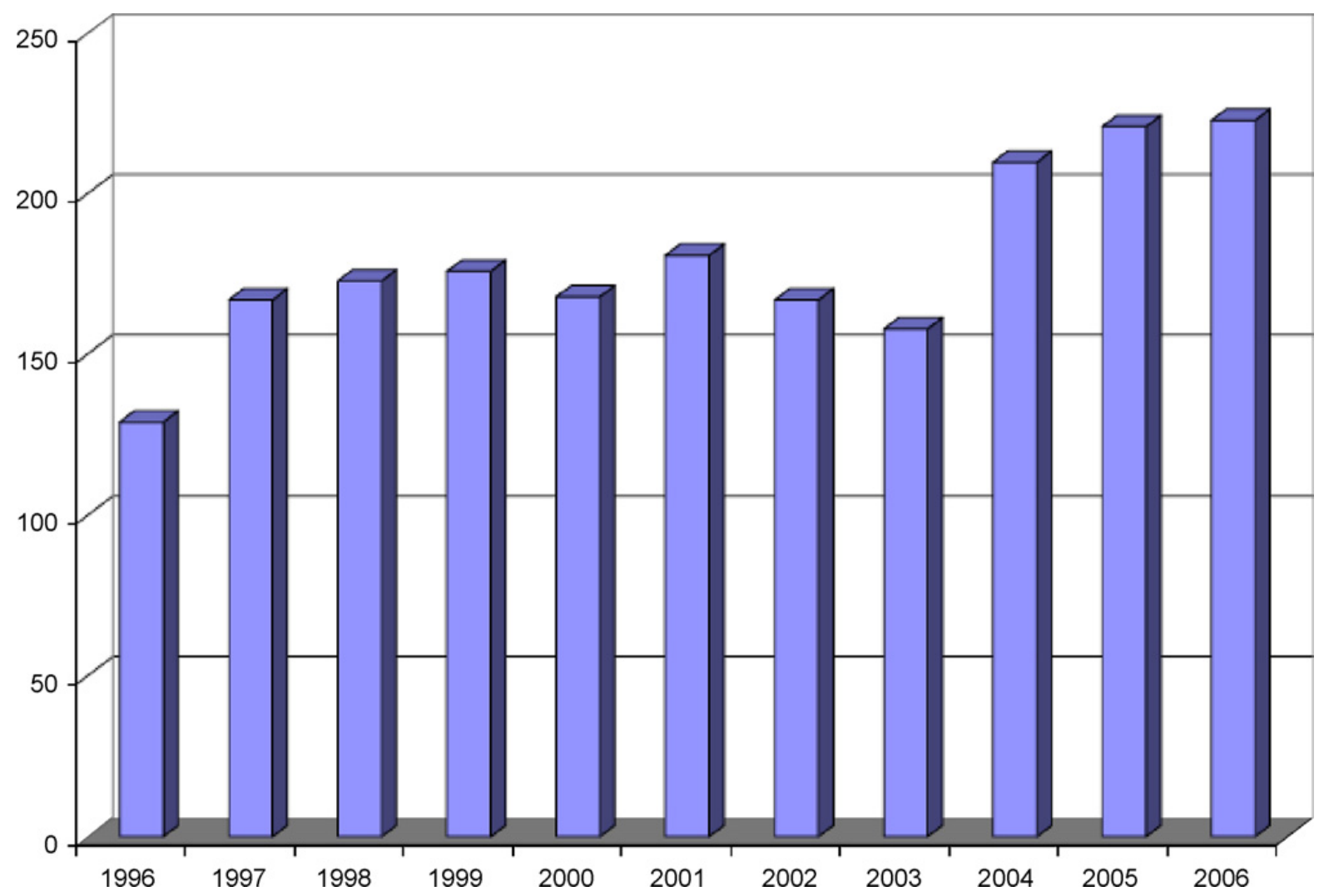

Fig. 1. FDI inflows into emerging markets and developing countries data in billion \$US. Data is from the IMF's Global Financial Stability Report, 2006. Data for 2005 is estimated and for 2006 is predicted (predictions taken from the IMF's World Economic Outlook).

Section 2 provides a brief survey of the extensive empirical work on the determinants of FDI inflows and of the very few papers that have looked at the nexus of FDI and capital account policies highlighting our contribution. Section 3 presents our empirical model and the data we use. Section 4 analyzes the results and Section 5 concludes.

\section{Empirical literature}

Recent contributions to the literature on the determinants of FDI inflows are summarized in Table 2. This literature is quite large, with much of it focusing on an OECD dataset of out-bound bi-lateral dataset of FDI flows. A recent survey of this literature and the micro-empirical literature on the industrial-organizational foundations of FDI is provided in Blonigen (2005). Another strand of the literature on capital flows examines the impact of capital account policies on other variables such as the volumes of short-term capital flows (the so-called 'hot money') or the volume and price of investment in the receiving country. Notable recent contributions in this strand include Henry (2003), Edwards and Rigobon (2005) on the Chilean case, Carvalho and Garcia (2006) on the Brazilian case, and a recent survey by Forbes (2006).

In the following discussion, we focus only on those papers that have examined the capital account-FDI nexus as this is the focus of our work. Desai, Foley, and Hines (2004), using firm level data from the U.S., find that American multinationals manage to circumvent capital controls by adjusting their reported intra-firm trade, affiliate profits and dividend repatriations. On the other hand, they identify a number of ways in which capital controls make operations more costly to the foreign affiliate, and thereby reduce FDI inflows significantly. American affiliates are about 
Table 2

Macroeconomic determinants of foreign direct investment inflows in developing countries

\begin{tabular}{|c|c|c|c|}
\hline Authors & Sample & Capital controls data & Impact on FDI \\
\hline Aizenman and Noy (2006) & 81 countries, $1982-1998$ & AREAR & $\begin{array}{l}\text { GDP per capita }(+) \text {, goods trade }(+) \text {, trade in incomes } \\
(+) \text {, foreign growth }(+) \text {, corruption }(-)\end{array}$ \\
\hline Albuquerque, Loayza, and Servén (2005) & 74 developing, 1970-1999 & & $\begin{array}{l}\text { G3 interest rates }(-) \text {, US yield curve slope }(-) \text {, World } \\
\text { growth }(-) \text {, GDP growth }(+) \text {, trade openness }(+) \text {, } \\
\text { financial depth }(+) \text {, government consumption }(-) \text {, GDP } \\
\text { growth volatility }(-)\end{array}$ \\
\hline Asiedu and Lien (2004) & 96 developing, 1970-2000 & AREAR & $\begin{array}{l}\text { Trade openness }(+) \text {, GDP per capita }(-,+ \text { for square), } \\
\text { fixed domestic investment }(+) \text {, telephones }(+) \text {, oil } \\
\text { exports }(-) \text {, political instability }(-)\end{array}$ \\
\hline Chakrabarti (2001) & Cross-section, 1994 & & $\begin{array}{l}\text { Sensitivity analysis: only GDP per capita, and GDP in } \\
\text { PPP\$ are robust. }\end{array}$ \\
\hline Desai et al. (2004) & Micro data on US MNE & AREAR; Shatz, 2000 & \\
\hline Gastanaga, Nugent, and Pashamova (1998) & 49 developing, 1970-1995 & AREAR & $\begin{array}{l}\text { Controls }(-) \text {, tax rate }(-) \text {, tariff }(-) \text {, past growth }(+) \text {, } \\
\text { future growth }(+)\end{array}$ \\
\hline Montiel and Reinhart (1999) & 15 emerging, 1990-1996 & Reinhart and Reinhart, 1998 & $\begin{array}{l}\text { Nothing significant on volume of FDI. Composition } \\
\text { changes with capital controls, US interest rate and } \\
\text { monetary policy }\end{array}$ \\
\hline Wei (2000) & Bilateral cross-section & & $\begin{array}{l}\text { Corruption }(-) \text {, tax }(-) \text {, population }(+) \text {, distance }(-) \text {, } \\
\text { linguistic tie }(+) \text {, wage }(+)\end{array}$ \\
\hline
\end{tabular}


$15 \%$ smaller in countries with capital controls and, importantly, this reduction disappears once countries open up their capital accounts.

Montiel and Reinhart (1999) examine the impact of capital account policies and sterilized foreign exchange interventions on the volume and composition of capital flows using a policy index they developed for the period 1990-1996. They conclude that imposing capital controls had no impact on volumes of flows but did shift the composition of flows toward short term 'hot money' - flows. Alfaro, Chanda, Kalemli-Ozcan, and Sayek (2004), and Aizenman and Noy (2003), also find that capital controls have no impact on aggregate capital flow volumes. Aizenman and Noy (2006), find that while capital controls have no impact on FDI gross flows, controls on the current account do have an indirect impact on FDI inflows through their impact on goods trade.

The paper closest to ours is Asiedu and Lien (2004). In this paper, the authors use a crosscountry macro panel of net FDI flows to examine the impact of external policies (viz., controls on the capital account, exchange rate regime and a surrender of export proceeds requirement) on net FDI flows. They present mixed findings with some evidence that FDI flows are impacted by capital account policies but only in specific geographical regions.

In light of these puzzling or conflicting results, and the prominence of policy debates on these issues, it is clear that more research into the capital flows/capital account policies nexus is desirable. Our paper differs from the previous literature described above in several ways. First, as our dependent variable we use net FDI inflows (FDI inflows minus repatriated investments) instead of the Asiedu and Lien (2004) measure of net FDI flows (net FDI inflows minus directinvestment-abroad/net-FDI-outflows) or Aizenman and Noy (2006) measure of FDI gross flows. Secondly, we use a different measure of capital controls that was recently developed by Chinn and Ito (2006) instead of the dichotomous measure used in almost all of the previous literature.

Thirdly, measures of capital controls are based on a de jure state, but it is likely that the de facto state of enforcement of these regulations is of considerable importance in identifying any empirically observable link. It is also probable that the de facto state is influenced by institutional characteristics of the receiving economy. Consequently, we examine the impact of institutional factors - corruption and political stability - on the degree of association between capital controls and the flows of FDI. Finally, as is described and reasoned in the following sections, our data coverage and empirical estimation methodology are different.

\section{Methodology and data}

\subsection{Data}

We constructed a macroeconomic annual panel dataset for 62 developing and 21 developed countries from 1984 to $2000 .^{8}$ Blonigen and Wang (2005) argue that pooling developed and developing countries is inappropriate in empirical FDI studies. Besides other differences, they find that the factors that affect FDI inflows are different across the two groups. We therefore conduct all of our analyses separately for developed and developing countries. ${ }^{9}$

Data for FDI are taken from the IMF's Balance of Payments Statistics database. The measure we use is for net FDI inflows (foreign direct investment inflows minus repatriated foreign invest-

\footnotetext{
${ }^{8}$ We use dummy variables to fill most of the missing observations but still have several missing observations, so we have an unbalanced panel. If there were more than 3 missing observations for one country for a single variable, we used a binary replacement variable to enable us to include the observations in the regressions.

9 Developed countries are defined based on the World Bank's classification system.
} 
ments). FDI is defined by the IMF as investment by foreigners that acquire a management interest ( $10 \%$ or more of voting stock). It is the sum of equity capital, reinvestment of earnings, and other long-and short-term capital. ${ }^{10}$

An analysis of available data on capital controls is available in Edison, Klein, Ricci, and Sløk (2004). The most popular source for data is the IMF's publication, Annual Report on Exchange Arrangements and Exchange Restrictions (AREAR). Most authors use a binary variable on the existence/absence of restrictions on the capital account taken from the AREAR data. As is argued in Edison et al. (2004), and Chinn and Ito (2006), this dichotomous measure is imperfect since there are a variety of ways and grades in which the capital account can be restricted. Since construction of a complete dataset on the full menu of capital restrictions makes cross-country empirical estimation impractical, we instead consider a continuous index that includes other components of external policies for which data is available in the AREAR database.

The indicator of capital account openness we employ was developed in Chinn and Ito (2006). They used the data reported in the AREAR on the existence of multiple exchange rates, restrictions on the current and capital accounts (where the latter is measured as the proportion of the last five years without controls) and requirements to surrender export proceeds in order to capture the intensity of controls on capital account transactions. Their index of openness is the first standardized principal component of the four variables above, and ranges from -2.0 in the case of most control to 2.5 in the case of most liberalization. We generate a new variable, KAOPN, to eliminate the negative sign: $\mathrm{KAOPN}=(\mathrm{CHINNITO}+2) / 4.5$. This data is available for 108 developed and developing countries for 1970-2000.

The additional macroeconomic and institutional data used for control variables in the regressions is taken from the World Bank's World Development Indicators and the PRS Group's International Country Risk Guide, respectively. Details on the variables' definitions and sources are available in the appendix.

\subsection{Methodology}

We start with a standard FDI determination model:

$$
\mathrm{FDI}_{i t}=\alpha_{t} D_{t}+\beta X_{i t}+\varepsilon_{i t}
$$

with time fixed-effects $\left(D_{t}\right)$ and a comprehensive list of independent variables $\left(X_{i t}\right)$ obtained from the previous research that is detailed in Table 2. We follow a downward piecewise algorithm in pairing down our specification in order to avoid omitted variables. We gradually eliminate variables with high multi-colinearity, using the Variance Inflation Factors test (VIF). The test uses the diagonal elements of the covariance matrix in a regression and is given by: $\operatorname{VIF}_{i}=\left(1-R_{i k}^{2}\right)^{-1}$, where $R_{i k}^{2}$ is the $R^{2}$ from regressing the $X_{i}$ on $k$ other variables. When there is perfect multicolinearity, $R_{i k}^{2}$ equals to one, and the VIF approaches infinity. Kennedy (2003) recommends that any variable with VIF greater than ten be eliminated.

For the developing countries dataset, we obtain 18 variables with $\mathrm{VIF}<10$. The 18 explanatory variables are: corruption (CORR — with the higher value denoting less corruption); financial risk

\footnotetext{
10 The net FDI flows variable that is conventionally employed (taken from the IMF's Balance of Payments Statistics or the World Bank's World Development Indicators) is the net FDI inflows we use minus net FDI outflows. That measure thus includes also outward FDI (investment by domestic resident firms in foreign countries and the repatriation of that investment). Outward FDI (net FDI outflows) is most likely determined by other factors so we do not include it. More details are available in: International Monetary Fund (2000).
} 
rating (FIN—with higher value denoting less financial risk), political risk rating (POLI-with higher value denoting less political risk), exports (EXP), GDP growth rate (GDPG), GDP per capita (GDPPCL), GDP growth volatility (GDPGV), interest rate controls (INTR), lagged value of FDI net inflows (FDIL), gross fixed capital formation (GFCF), inflation (INFL), economic stability (ECON), life expectancy (LIFE), literacy rate (LITER), government consumption (GCONS), ratio of deposit money bank assets to GDP (DMAGDP), private credit by deposit money banks and other institutions to GDP (PCDMO), and exchange rate volatility (EXCHAV). ${ }^{11}$

We also add fixed effect (time and country effects) and the capital control variables of interest to obtain:

$$
\mathrm{FDI}_{i t}=\alpha_{t} D_{t}+\gamma_{i} D_{i}+\beta X_{i t}+\delta \mathrm{KAOPN}_{i t}+\varepsilon_{i t}
$$

Finally, in order to examine whether the impact of capital controls on FDI inflows is sensitive to different institutional and political-economic differences in the destination economies, we estimate Eq. (2) and also include KACOR (interaction between capital openness and corruption), KAFIN (capital openness and financial risk), and KAPOL (capital openness and political instability).

\section{Results}

In Table 3, we first describe and report on our benchmark specifications - these regressions include all of the control variables but do not include the capital account policy variables. We report separately specifications for developing (non-developed) and developed countries (fixed effects and OLS). We obtain the following general results: For the developing country sample, there is evidence of a negative impact of corruption on FDI inflows, and a negative effect of financial risk with the opposite effect for political risk. ${ }^{12}$ These results disappear in a fixed effect specification since these variables do not change much over time. For this sample, we also observe a positive association between exports and FDI inflows, a negative impact of past GDP growth volatility and a positive impact of gross fixed capital formation. All these results correspond closely with much of the previous research described in Table 2. For the developed countries sample, we observe a similar pattern for exports and GDP growth volatility. In addition, we see some counter-intuitive evidence of a positive impact of inflation, and a negative impact of GDP growth. The explanatory power (adjusted $R^{2}$ ) of these models is between 0.34 and 0.57 . All the regression specifications results described hence (in Tables 4-6) also contain all of the control variables described above (in Table 3).

In Table 4, we report the full specification of our empirical model including the capital account openness variable. In all instances (developing and developed countries and in the fixed and OLS specifications) the capital account openness measure is positively associated with the amount of FDI inflows after controlling for all other macroeconomic and institutional measures.

For the OLS estimates, the coefficient for the developing countries sample is smaller. But, once we control for country-specific time-invariant effects (fixed effects), we find that the impact of capital account openness is much bigger for developing countries. Since in our sample period, changes in capital account policies were much more prevalent in the developing countries sample,

\footnotetext{
${ }^{11}$ In a previous version, we also included regressions with a more parsimonious specification that includes only 11 explanatory variables whose coefficients have a $p>0.5$ of being different from zero. Results, however, are insensitive to the elimination or inclusion of these variables.

12 See Aizenman and Noy (2003) for a similar result and a theoretical model explaining it.
} 
Table 3

FDI determinants without capital openness

\begin{tabular}{|c|c|c|c|c|}
\hline \multirow[t]{2}{*}{ Variable } & \multicolumn{2}{|c|}{ Developing countries } & \multicolumn{2}{|l|}{ Developed countries } \\
\hline & OLS (1) & FE (2) & OLS (3) & $\mathrm{FE}(4)$ \\
\hline CORR & $.1852 *(.0995)$ & $.0756(.1866)$ & $.3224(.2156)$ & $.4836 *(.2734)$ \\
\hline FIN & $-.0356 * *(.0163)$ & $-.0263(.0174)$ & $.0062(.0315)$ & $-.0126(.0457)$ \\
\hline POLI & $.0272 * *(.0127)$ & $.0126(.0183)$ & $.0034(.0279)$ & $.0306(.0383)$ \\
\hline EXP & $.0224 *(.0086)$ & $.0275(.0182)$ & $.0393 * * *(.0075)$ & $.1126(.0758)$ \\
\hline GDPG & $.0282(.0213)$ & $.0256(.0259)$ & $.1243 * *(.0591)$ & $.0809(.0688)$ \\
\hline GDPPCL & $-.00003(.00003)$ & $-.0002(.0003)$ & $-.00009 * * *(.00004)$ & $.00004(.0002)$ \\
\hline GDPGV & $-.0815^{*}(.0494)$ & $-.1487(.1544)$ & $-.3502 * *(.1414)$ & $-6654(1.558)$ \\
\hline INTR & $-.00003(.00003)$ & 4.87e-06 (.00004) & $-.0098(.0066)$ & $-.0038(.0064)$ \\
\hline FDIL & $.3634 * * *(.1232)$ & $.1912 *(.1166)$ & $.3954 * * *(.1241)$ & $.2906 * *(.1225)$ \\
\hline GFCF & $.0306 * * *(.0098)$ & $.0705 * * *(.0224)$ & $-.0684(.0502)$ & $-.0202(.0878)$ \\
\hline INFL & $-.00003(.00005)$ & $-.00027 * * *(.00008)$ & $.0645 * *(.0306)$ & $.0763 * *(.0380)$ \\
\hline ECON & $.0013(.0246)$ & $.0032(.0325)$ & $.0047(.0132)$ & $-.0065(.0143)$ \\
\hline LIFE & $.00004(.0002)$ & $.00008(.00056)$ & $-.0005(.0062)$ & $.0008(.0054)$ \\
\hline LITER & $-.0021(.0153)$ & $-.0046(.0312)$ & $.0087(.0435)$ & $.0045(.0137)$ \\
\hline GCONS & $.0215(.0943)$ & $.0425(.1296)$ & $.0534(.1346)$ & $.0823(.2539)$ \\
\hline DMAGDP & $.0058(.0233)$ & $.0073(.0423)$ & $.0035(.0153)$ & $.0067(.0372)$ \\
\hline PCDMO & $.0007(.0013)$ & $.0009(.0045)$ & $.00006(.0003)$ & $-.00003(.0024)$ \\
\hline EXCHAV & $.0154(.1326)$ & $.0362(.1546)$ & $.0233(.1435)$ & .0465 (.1439) \\
\hline No. of obs & 773 & 776 & 307 & 310 \\
\hline F-Stat & 11.02 & 11.26 & 7.87 & 8.45 \\
\hline Prob $>F$ & .0000 & .0000 & .0000 & .0000 \\
\hline R-squared & .3435 & .4534 & .5439 & .5732 \\
\hline Root MSE & 2.132 & 2.012 & 1.954 & 1.993 \\
\hline
\end{tabular}

The $* * *$, and $* * *$ indicate $10 \%, 5 \%$, and $1 \%$ significance levels, respectively. The standard errors are in parentheses. Dependent variable: FDI inflows.

Table 4

FDI determinants with capital openness

\begin{tabular}{llllll}
\hline Variable & \multicolumn{2}{l}{ Developing Countries } & & \multicolumn{2}{l}{ Developed Countries } \\
\cline { 2 - 3 } \cline { 5 - 6 } & OLS $(1)$ & & OLS $(3)$ & FE $(4)$ \\
\hline KAOPN1 & $.7323^{*}(.4082)$ & $1.196^{* * *}(.4438)$ & & $1.303 * *(.5605)$ & $.4063(.6151)$ \\
CORR & $.1874 *(.0995)$ & $.0835(.1868)$ & & $.3369(.2165)$ & $.4816 *(.2968)$ \\
FIN & $-.0363 * *(.0168)$ & $-.0321(.0176)$ & & $-.0135(.0323)$ & $-.0186(.0459)$ \\
POLI & $.0276^{* *}(.0124)$ & $.0099(.0187)$ & & $-.0102(.0277)$ & $.0275(.0398)$ \\
FDIL & $.3574 * *(.1225)$ & $.1836(.1155)$ & & $.3843 * * *(.1240)$ & $.2903 * *(.1227)$ \\
No. of obs & 772 & 776 & 307 & 310 \\
F-Stat & 11.23 & 10.45 & & 10.19 & 8.56 \\
Prob $>$ F & .0000 & .0000 & .0000 & .0000 \\
R-squared & .3536 & 2.016 & & .5754 & .5787 \\
Root MSE & 2.132 & & 1.925 & 1.925 \\
\hline
\end{tabular}

The *,**, and $* * *$ indicate $10 \%, 5 \%$, and $1 \%$ significance levels, respectively. The standard errors are in parentheses. All specifications also include all the control variables included in Table 3. Complete results are available from the authors upon request. Dependent variable: FDI inflows. 
Table 5

FDI determinants with capital openness and interaction terms: developing countries

\begin{tabular}{|c|c|c|c|c|c|c|}
\hline \multirow[t]{2}{*}{ Variable } & \multicolumn{3}{|l|}{ OLS } & \multicolumn{3}{|l|}{$\mathrm{FE}$} \\
\hline & (1) & (2) & (3) & (4) & (5) & (6) \\
\hline KAOPN1 & $-1.342 *(.8151)$ & $1.364(1.557)$ & $-2.113(1.696)$ & $-1.024(.9827)$ & $.5256(1.715)$ & $-3.585^{*}(1.912)$ \\
\hline KACOR & $.6778 * *(.2867)$ & & & $.8005^{* * * *}(.3007)$ & & \\
\hline KAFIN & & $-.0225(.0444)$ & & & $.0194(.0479)$ & \\
\hline KAPOL & & & $.0453 *(.0239)$ & & & $.0784 * *(.0317)$ \\
\hline CORR & $-.0286(.1345)$ & $.1885^{*}(.0998)$ & $.1896 *(.0985)$ & $-.1268(.1951)$ & $.0806(.1862)$ & $.1025(.1867)$ \\
\hline FIN & $-.0368 * *(.0167)$ & $-.0275(.0186)$ & $-.0346 * *(.0167)$ & $.0316^{*}(.0169)$ & $-.0403 *(.0232)$ & $-.0296 *(.0171)$ \\
\hline POLI & $.0287 * *(.0129)$ & $.0273 * *(.0126)$ & $.0132(.0138)$ & $.0086(.0187)$ & $.0117(.0196)$ & $-.0132(.0197)$ \\
\hline FDIL & $.3516^{* * *}(.1222)$ & $.3566 * * *(.1227)$ & $.3527 * * *(.1223)$ & $.1802(.1258)$ & $.1836(.1259)$ & $.1783(.1168)$ \\
\hline No. of obs & 772 & 772 & 772 & 776 & 776 & 776 \\
\hline F-Stat & 11.02 & 11.14 & 11.21 & 11.02 & 10.92 & 11.32 \\
\hline Prob $>F$ & .0000 & .0000 & .0000 & .0000 & .0000 & .0000 \\
\hline R-squared & .3643 & .3586 & .3575 & .4634 & .4645 & .4676 \\
\hline Root MSE & 2.103 & 2.135 & 2.113 & 2.013 & 2.132 & 2.015 \\
\hline
\end{tabular}

The ***, and $* * *$ indicate $10 \%, 5 \%$, and $1 \%$ significance levels, respectively. The standard errors are in parentheses. All specifications also include all the control variables included in Table 3. Complete results are available from the authors upon request. Dependent variable: FDI inflows. 
Table 6

FDI determinants with capital openness and interaction terms: developed countries

\begin{tabular}{|c|c|c|c|c|c|c|}
\hline \multirow[t]{2}{*}{ Variable } & \multicolumn{3}{|l|}{ OLS } & \multicolumn{3}{|l|}{$\mathrm{FE}$} \\
\hline & (1) & (2) & (3) & (4) & (5) & (6) \\
\hline KAOPN1 & $-6.145^{* *}(2.559)$ & $1.341(2.045)$ & $-12.25 * *(5.267)$ & $-8.902 * * *(2.502)$ & $-5.013(5.563)$ & $-26.62 * * *(6.576)$ \\
\hline KACOR & $1.404 * * *(.4682)$ & & & $1.894 * * *(.5273)$ & & \\
\hline KAFIN & & $.0013(.0679)$ & & & $.1282(.1543)$ & \\
\hline KAPOL & & & $.1785^{* * *}(.0642)$ & & & $.3643 * * *(.0863)$ \\
\hline CORR & $-.9582 * *(.4376)$ & $.3364(.2341)$ & $.2518(.2179)$ & $-1.032 * * *(.2435)$ & $.4243^{*}(.2435)$ & $.3414(.3722)$ \\
\hline FIN & $.0024(.0312)$ & $-.0145(.0514)$ & $0191(.0326)$ & $-.0003(.0485)$ & $-.1305(.1567)$ & $.0165(.0446)$ \\
\hline POLI & $.0234(.0306)$ & $-.0106(.0329)$ & $-.1163 * * *(.0401)$ & $.0672(.0725)$ & $.0354(.0408)$ & $-.2255^{* * *}(.0638)$ \\
\hline FDIL & $.3714 * * *(.1201)$ & $.3846^{* * *}(.1252)$ & $3724 * * *(.1196)$ & $.2746^{* *}(.1184)$ & $.2892 * *(.1228)$ & $.2695 * *(.1254)$ \\
\hline No. of obs & 307 & 307 & 307 & 310 & 310 & 310 \\
\hline F-Stat & 9.98 & 10.01 & 9.92 & 8.78 & 8.82 & 10.97 \\
\hline Prob $>F$ & .0000 & .0000 & .0000 & .0000 & .0000 & .0000 \\
\hline $\mathrm{R}$-squared & .5864 & .5765 & .5876 & .5891 & .5713 & .5935 \\
\hline Root MSE & 1.914 & 1.934 & 1.913 & 1.956 & 1.985 & 1.936 \\
\hline
\end{tabular}

The *,**, and *** indicate $10 \%, 5 \%$, and $1 \%$ significance levels, respectively. The standard errors are in parentheses. All specifications also include all the control variables included in Table 3. Complete results are available from the authors upon request. Dependent variable: FDI inflows. 
the disappearance of the capital policies' effect in the developed country panel is not surprising. For the developed country sample, any identified impact of capital openness is apparently due to country specific characteristics that we are unable to control for.

As for the economic significance of this effect, we find that an increase of one standard deviation in the capital openness index will increase FDI inflows by $0.71 \%$ and $0.32 \%$ (of the receiving country's GDP) for the developing and developed countries samples, respectively. ${ }^{13}$ While statistically significant, it appears that capital account liberalization increases FDI inflows only modestly.

Tables 5 and 6 investigate the interaction between the institutional factors, as proxies for enforcement of the capital account regulations, and the regulations themselves in determining the amount of FDI inflows. In Table 5, we note that the previously reported clear-cut positive association between capital account openness and FDI inflows no longer holds once we control for the interactions of institutions/enforcement. The most interesting result, in our view, is that capital openness seems to be effective in generating more FDI inflows only if the level of corruption is low. Apparently, either capital controls are more easily circumvented in a corrupt environment or capital openness, in and of itself, is not enough to generate increases in inflows unless it is accompanied by a decrease in the level of corruption. We obtain similar results for political risk. Liberalized capital account is only efficient in generating more inflows in an environment of low political risk.

Interestingly, thee findings for corruption and political risk hold for both OLS and fixed effects versions of the estimated model, suggesting that the effect is also of importance over time. In Table 6 we present similar results for the developed countries sample.

In a first attempt to establish robustness, we provide, in appendix B, results for benchmark regressions using the conventional binary indicator for capital account openness based on the AREAR data. For all the control variables, results are very similar to the ones previously reported. The coefficient for the binary indicator of capital account openness, on the other hand, is now occasionally negative and significant (in the OLS specification for developing countries and in the fixed effects specification for developed countries). This may mean that capital account openness leads to decreases in the volumes of FDI inflows. More probable, in our view, is that this binary measure is too crude a measure of the capital account regime and that our results, namely that degree of capital account openness does not matter unless one accounts for corruption and institutional stability, is the more likely interpretation.

To further examine robustness we also utilize a different way to examine the differential impact of capital account openness on FDI inflows for high/low corruption or high/low politically stable regime. We divide the sample into low/high corruption observations with the median corruption level used as a threshold. We ran key specifications separately for each sub-sample (high/low level of corruption), and then compare the coefficients on the capital account variable. As expected, in light of our previous results, capital account openness does lead to more FDI inflows in low corruption country-year observations but may lead to even less FDI inflows in high corruption states. ${ }^{14}$

Very similar conclusions also result from dividing the sample into low/high financial and political stability environments. For developing countries, a financially and politically stable environment allows the economy to reap the benefits of capital account openness with additional FDI inflows. This is never the case for financially and politically unstable regimes, where openness does not result in any statistically observable increase in FDI inflows. All of these results are available upon request.

\footnotetext{
13 These calculations are based on the coefficients obtained in specifications 4.2 and 4.4, respectively.

14 This result holds for developing countries. For developed countries, we again see a more beneficial impact of openness in low corruption states but the difference and statistical significance are much lower.
} 
Since we view these set of results as an interesting contribution to the literature, we verify their robustness using two other measures of political stability and a proxy for corruption. We use and index of political freedom (the measure sums up the political rights and civil liberties indices available from Freedom House) and an index that measures the durability of a political regime (based on past regime changes - this measure is the DURABLE index from the Polity IV dataset). We utilize a measure of the degree of democracy in a political regime as a proxy for corruption, since an alternative direct measure of corruption with similar panel coverage is not available. ${ }^{15}$ Results remain qualitatively the same and similarly significant with the coefficients slightly larger when the Freedom House index and slightly smaller when relying on the Polity IV measure.

The measurement of capital controls is fraught with difficulty. ${ }^{16}$ While the measure we have used is somewhat more nuanced than the oft-used binary measure obtained from IMF publications, we clearly need to establish the robustness of our results using alternative measures. In recent work, Edwards (in press) constructed an index of de jure capital mobility by combining information from Quinn (2003) and Mody and Murshid (2002) with information from country-specific sources. This new index has a scale from 0 to 100 , where higher numbers denote a higher degree of de jure capital mobility. ${ }^{17}$ The results obtained using the Edwards capital openness index are qualitatively very similar to the ones we obtained from the Chinn-Ito index and are presented in an appendix (tables C-E). ${ }^{18}$

It might be the case that the magnitude of foreign direct investment inflows dictate or change the incentives of governments in adopting capital account policy - a problem of endogeneity. We carry out endogeneity tests for developing and developed countries. First, capital openness is regressed against all other variables, and residual of this regression is saved. In the second step, we regress the structural equation on capital openness and all other variables with the residual of the first regression added. If there is an endogeneity problem, this residual will be significantly different from zero. ${ }^{19}$ The p-value of the estimated coefficient for this residual is 0.852 for developing countries and 0.470 for developed countries. Based upon these results, we fail to reject the null hypothesis that this residual is not significantly different from zero and, hence, we conclude that there is no evidence of endogeneity, and 2SLS estimation is not needed.

In order to ensure that endogeneity is indeed not biasing our results, we also ran the main specifications using an estimation methodology that accounts for a possible endogeneity in the RHS variables. We implement the commonly used Arellano and Bond (1991) GMM dynamic two-step panel estimator. In Tables 7 and 8, where these results are reported, we also report the statistics for autocorrelation and the Sargan test of over-identifying restrictions (these are derived in Arellano \& Bond, 1991). The results we obtain are qualitatively and quantitatively almost identical to those we obtained using the fixed effect least squares estimator while, as can be expected, the increased efficiency of the GMM algorithm leads to much higher t-statistics. This confirms our previous finding that endogeneity does not appear to bias our results.

We also carry out a Granger-causality test. Capital openness is regressed against three lagged values of FDI and its own three lags in addition to the other control variables. The p-value of the

\footnotetext{
15 This measure aggregates annual measures for both institutionalized democracy (DEMOC) and autocracy (AUTOC)

“. . . this procedure provides a single regime score that ranges from +10 (full democracy) to -10 (full autocracy)." (Marshall and Jaggers, 2000, p. 12).

16 See Edison et al. (2004).

17 For details on this index, see Edwards (in press). The data is available for 1970-2004 for 163 countries (with many missing observations).

18 The statistical significance of the results is somewhat weaker.

19 This is a modified Hausman test described in Kennedy (2003, pp. 172-173).
} 
Table 7

A-B GMM estimations: FDI determinants with capital openness developing countries

\begin{tabular}{|c|c|c|c|c|}
\hline Variable & (1) & (2) & (3) & (4) \\
\hline KAOPN1 & $1.4901 * * *(.0083)$ & $-.6332(.4213)$ & $-.1755 * * *(.4134)$ & $-9.158 * * *(.6829)$ \\
\hline KACOR & & $.7509 * * *(.1155)$ & & \\
\hline KAFIN & & & $.0893 * *(.0497)$ & \\
\hline KAPOL & & & & $.1744 * * *(.0098)$ \\
\hline CORR & .0795 (.1834) & $.2158 *(.1256)$ & $-.0799(.1732)$ & $.0573 *(.0335)$ \\
\hline FIN & $-.0286 * * *(.0027)$ & $-.0461 * * *(.0093)$ & $-.0892 * * *(.0062)$ & $-.0304 * * *(.0021)$ \\
\hline POLI & $.0294 * * *(.0019)$ & $.02764 * * *(.0034)$ & $.0360 * * *(.0027)$ & $.0431(.0398)$ \\
\hline FDIL1 & $.0784 * * *(.0016)$ & $.0830 * * *(.0027)$ & $.0719 * * *(.0046)$ & $.4134 * * *(1585)$ \\
\hline FDIL2 & $-.0168 * * *(.0041)$ & $-.0125 * * *(.0014)$ & $-.0185 * * *(.0065)$ & $.2984 * * *(.0893)$ \\
\hline No. of obs & 859 & 859 & 859 & 859 \\
\hline No. of group & 62 & 62 & 62 & 62 \\
\hline Sargan Over-identification statistic (150) & 53.02 & 57.11 & 58.25 & 51.13 \\
\hline $\mathrm{z}$-value for autocorrelation & -.20 & -.22 & -.13 & .24 \\
\hline
\end{tabular}

The *,**, and $* * *$ indicate $10 \%, 5 \%$, and $1 \%$ significance levels, respectively. The standard errors are in parentheses. All specifications also include all the control variables included in Table 3. Complete results are available from the authors upon request. The model is estimated with the two-step Arellano-Bond GMM dynamic panel methodology using two lags of the FDI variable. Dependent variable: FDI inflows. 
Table 8

A-B GMM estimations: FDI determinants with capital openness developed countries

\begin{tabular}{|c|c|c|c|c|}
\hline Variable & (1) & (2) & (3) & (4) \\
\hline KAOPN & $-.6104(.8927)$ & $-13.54 *(8.013)$ & $-24.11(28.55)$ & $-21.11 *(13.98)$ \\
\hline KACOR & & $1.930 *(1.152)$ & & \\
\hline KAFIN & & & $.1245(.1309)$ & \\
\hline KAPOL & & & & $.2686 * *(.1314)$ \\
\hline CORR & $.1425(.1352)$ & $-1.275(2.564)$ & $.0606(.1720)$ & $-.1077(.1149)$ \\
\hline FIN & $-.0598 * * *(.0144)$ & $-.0657(.0661)$ & $-.1171(.1143)$ & $-.0520(.0320)$ \\
\hline POLI & $.0189(.0156)$ & $.0127(.0455)$ & $.0319 *(.0182)$ & $-.2181 *(.1203)$ \\
\hline FDIL1 & $.4132 * * *(.1006)$ & $.4609^{* * *}(.1215)$ & $.3173 * *(.1569)$ & $.4264 * * *(1110)$ \\
\hline FDIL2 & $.2984 * * *(.0893)$ & $.2601(.1801)$ & $.3698 * * *(.1301)$ & $.3217 * * *(.1346)$ \\
\hline No. of obs & 292 & 292 & 292 & 292 \\
\hline No. of group & 21 & 21 & 21 & 21 \\
\hline Sargan Over-identification statistic (150) & 12.16 & 12.29 & 11.72 & 12.45 \\
\hline $\mathrm{z}$-value for autocorrelation & -.1 .49 & -.16 & -.78 & -.38 \\
\hline
\end{tabular}

The $* * *$, and $* * *$ indicate $10 \%, 5 \%$, and $1 \%$ significance levels, respectively. The standard errors are in parentheses. All specifications also include all the control variables included in Table 3. Complete results are available from the authors upon request. The model is estimated with the two-step Arellano-Bond GMM dynamic panel methodology using two lags of the FDI variable. Dependent variable: FDI inflows. 
F test for joint significance of the three FDI lags is 0.428 for developing countries and 0.368 for developed countries. We thus fail to reject the null hypothesis that the coefficients of these lags are not significantly different from zero. We conclude that FDI does not appear to Granger-cause capital openness, and simultaneous equation estimations are not needed.

\section{Conclusions}

Our basic finding from the benchmark model is clear and intuitive: the capital account openness measure is positively but moderately associated with the amount of FDI inflows after controlling for other macroeconomic and institutional measures. Yet, the clear-cut positive association between capital account openness and FDI inflows no longer holds once we control for the interactions with institutional quality and enforcement. Capital controls are easily circumvented in corrupt and politically unstable environments, and capital account liberalization will generate increases in FDI inflows only in environments with a lower level of corruption and political risk.

Furthermore, our measure of capital controls examines the rules that govern capital flows that are 'on the books' (a de jure measure). It is plausible that the degree of enforcement of these regulations differs across countries and across time. We expect enforcement of these regulations to interact with the de jure measure in its impact on actual flows; though de jure rules might also have a separate impact since there is a degree of uncertainty with regard to future enforcement policy. While we tried to control for enforcement using institutional proxies, their correlation with actual enforcement is unclear.

We believe more details on the intensity of rules may provide a more nuanced picture of the impact of regulations on de facto FDI inflows than one is able to discern using the cruder measures of capital controls that are generally used. Specific case studies that report on the impact of the exact regulations in place might shed more light on these questions. Clearly, the main drawback of this approach is a difficulty in discerning the general applicability of specific case studies.

\section{Appendix A. Data definitions and sources}

\begin{tabular}{|c|c|c|}
\hline Code & Definition of variable & Source \\
\hline FDI inflows & $\begin{array}{l}\text { Net inflows of investment that acquires a management interest } \\
\text { (10\% or more of voting stock) in an enterprise operating in an } \\
\text { economy other than that of the investor. }\end{array}$ & IMF-BOPS $^{\mathrm{a}}$ \\
\hline KAOPN1 & Capital controls index & Chinn and Ito (2005) \\
\hline KAOPN2 & Capital controls index & Edwards (in press) \\
\hline CORR & Corruption & PRS-ICRG ${ }^{\mathrm{b}}$ \\
\hline FIN & Financial risk rating & PRS-ICRG \\
\hline POLI & Political risk rating & PRS-ICRG \\
\hline EXP & Exports & WB-WDI ${ }^{\mathrm{c}}$ \\
\hline GDPG & GDP growth & WB-WDI \\
\hline GDPPCL & GDP per capita & WB-WDI \\
\hline GDPGV & GDP growth volatility & Authors calculations \\
\hline INTR & Interest rate controls & Abiad and Mody (2005) \\
\hline GFCF & Gross fixed capital formation & WB-WDI \\
\hline INFL & Inflation & WB-WDI \\
\hline
\end{tabular}

\footnotetext{
a The IMF's Balance-of-Payments Statistics.

b The PRS Group's International Country Risk Guides.

c The World Bank's World Development Indicators.
} 


\section{Appendix B. FDI determinants with capital openness (Table 4 with the conventional binary capital openness variable)}

Dependent variable: FDI inflows

\begin{tabular}{|c|c|c|c|c|}
\hline \multirow[t]{2}{*}{ Variable } & \multicolumn{2}{|l|}{ Developing countries } & \multicolumn{2}{|c|}{ Developed countries } \\
\hline & OLS (1) & $\mathrm{FE}(2)$ & OLS (3) & FE (4) \\
\hline KAOPN & $-.7137 * * *(.2641)$ & $-.6016(.4289)$ & $.1533(.1460)$ & $-.5699 * * *(.1539)$ \\
\hline CORR & $.1800 * *(.0781)$ & $-.2040(.1360)$ & $.0670(.1160)$ & $.0593(.1344)$ \\
\hline FIN & $.0136(.0182)$ & $.0218(.0234)$ & $-.0390 *(.0218)$ & $.0278(.0263)$ \\
\hline POLI & $.0147(.0102)$ & $.0237(.0186)$ & $-.0199(.0153)$ & $-.0631(.0185)$ \\
\hline FDIL & $2888(.1769)$ & $.1516(.1676)$ & $.6473 * * *(.0658)$ & $.3123 * * *(.0750)$ \\
\hline No. of obs & 553 & 553 & 256 & 256 \\
\hline F-Stat & 7.62 & .1135 & 6.48 & 5.23 \\
\hline Prob $>F$ & .0000 & .8435 & .0000 & .0000 \\
\hline R-squared & .2760 & .3383 & .3802 & .3413 \\
\hline Root MSE & 1.906 & 1.845 & 2.126 & 2.132 \\
\hline
\end{tabular}

The $* * *$, and $* * *$ indicate $10 \%, 5 \%$, and $1 \%$ significance levels, respectively. The standard errors are in the parentheses. All specifications also include the following control variables: corruption, financial risk index, political risk index, exports (\% of GDP), GDP growth rate, GDP per capita, GDP growth volatility, interest rate controls, lagged value of FDI net inflows, gross fixed capital formation, and inflation. Complete results are available from the authors upon request.

\section{Appendix C. FDI Determinants with capital openness (Table 4 with the Edwards Index)}

Dependent variable: FDI inflows

\begin{tabular}{llllll}
\hline Variable & \multicolumn{2}{l}{ Developing countries } & & \multicolumn{2}{l}{ Developed countries } \\
\cline { 2 - 3 } & OLS $(1)$ & & OLS $(3)$ & FE (4) \\
\hline KAOPN2 & $.0095^{*}(.0050)$ & $.0031(.0062)$ & & $.0264 * * *(.0040)$ & $.0045(.0152)$ \\
CORR & $.1902^{*}(.0986)$ & $.0728(.1915)$ & & $.3348(.2171)$ & $.4644 *(.2969)$ \\
FIN & $-.0344^{*}(.0167)$ & $-.0274(.0173)$ & & $-.0338(.0354)$ & $-.0159(.0464)$ \\
POLI & $.0254^{*}(.0119)$ & $.0122(.0187)$ & & $-.0109(.0287)$ & $.0306(.0381)$ \\
FDIL & $.3451^{*} *(.1229)$ & $.1896(.1172)$ & & $.3855^{* * *}(.1184)$ & $.2914 * *(.1218)$ \\
No. of obs & 773 & 776 & & 307 & 310 \\
F-Stat & 11.24 & 10.94 & & 8.84 & 8.44 \\
Prob $>$ F & .0000 & .0000 & .0000 & .0000 \\
R-squared & .3560 & .4561 & & .5822 & .5721 \\
Root MSE & 2.1209 & 2.023 & 1.9010 & 1.987 \\
\hline
\end{tabular}

The $*, * *$, and $* * *$ indicate $10 \%, 5 \%$, and $1 \%$ significance levels, respectively. The standard errors are in the parentheses. All specifications also include the following control variables: corruption, financial risk index, political risk index, exports (\% of GDP), GDP growth rate, GDP per capita, GDP growth volatility, interest rate controls, lagged value of FDI net inflows, gross fixed capital formation, and inflation. Complete results are available from the authors upon request. 


\section{Appendix D. FDI Determinants with capital openness and interaction terms developing countries (Table 5 with the Edwards Index)}

Dependent Variable: FDI inflows

\begin{tabular}{|c|c|c|c|c|c|c|}
\hline \multirow[t]{2}{*}{ Variable } & \multicolumn{3}{|l|}{ OLS } & \multicolumn{3}{|l|}{$\mathrm{FE}$} \\
\hline & (1) & (2) & (3) & (4) & (5) & (6) \\
\hline KAOPN2 & $-.0083(.0133)$ & $.0246(.0171)$ & $-.0110(.0166)$ & $-.0317 * *(.0127)$ & $.0119(.0198)$ & $-.0379 * *(.0193)$ \\
\hline KACOR & $-.0062(.0050)$ & & & $.0119 * * *(.0044)$ & & \\
\hline KAFIN & & $-.0005(.0005)$ & & & $-.0003(.0006)$ & \\
\hline KAPOL & & & $.0004(.0003)$ & & & $.0007 * *(.0003)$ \\
\hline CORR & $-.0966(.2604)$ & $.1916^{*}(.0985)$ & $.1878 *(.0981)$ & $-.4720(.3167)$ & $.0823(.1938)$ & $.0526(.1912)$ \\
\hline FIN & $-.0331 * *(.0164)$ & $-.0095(.0269)$ & $-.0326 * *(.0168)$ & $.0261 *(.0158)$ & $-.0126(.0332)$ & $-.0242 *(.0174)$ \\
\hline POLI & $.0249 * *(.0118)$ & $.0238 * *(.0120)$ & $.0094(.0167)$ & $.0090(.0181)$ & $.0109(.0191)$ & $-.0209(.0254)$ \\
\hline FDIL & $.3512 * * *(.1223)$ & $.3524 * * *(.1228)$ & $.3522 * * *(.1229)$ & $.1816(.1161)$ & $.1884(.1173)$ & $.1869(.1168)$ \\
\hline No. of obs & 773 & 773 & 773 & 776 & 776 & 776 \\
\hline F-Stat & 11.13 & 11.22 & 11.04 & 11.16 & 10.81 & 10.95 \\
\hline Prob $>F$ & .0000 & .0000 & .0000 & .0000 & .0000 & .0000 \\
\hline R-squared & .3501 & .3568 & .3571 & .4617 & .4562 & .4587 \\
\hline Root MSE & 2.119 & 2.121 & 2.121 & 2.014 & 2.024 & 2.019 \\
\hline
\end{tabular}

The $* * *$, and $* * *$ indicate $10 \%, 5 \%$, and $1 \%$ significance levels, respectively. The standard errors are in the parentheses. All specifications also include the following control variables: corruption, financial risk index, political risk index, exports (\% of GDP), GDP growth rate, GDP per capita, GDP growth volatility, interest rate controls, lagged value of FDI net inflows, gross fixed capital formation, and inflation. Complete results are available from the authors upon request.

\section{Appendix E. FDI determinants with capital openness and interaction terms developed countries (Table 6 with the Edwards Index)}

Dependent variable: FDI inflows

\begin{tabular}{|c|c|c|c|c|c|c|}
\hline \multirow[t]{2}{*}{ Variable } & \multicolumn{3}{|l|}{ OLS } & \multicolumn{3}{|l|}{$\mathrm{FE}$} \\
\hline & (1) & (2) & (3) & (4) & (5) & (6) \\
\hline KAOPN2 & $-.0555^{*}(.0329)$ & $.0994(.0571)$ & $-.2169 *(.0825)$ & $-.0802 * *(.0392)$ & $.0216(.0845)$ & $-.3348 * * *(.0999)$ \\
\hline KACOR & $.0141 * *(.0059)$ & & & $.0157 * *(.0071)$ & & \\
\hline KAFIN & & $-.0016(.0012)$ & & & $-.0004(.0019)$ & \\
\hline KAPOL & & & $.0028 * * *(.0010)$ & & & $.0041 * * *(.0012)$ \\
\hline CORR & $-.9270 * *(.4964)$ & $.3661 *(.2124)$ & $.2691(.2138)$ & $-.8459(.5324)$ & $.4638(.2985)$ & $.4785(.2918)$ \\
\hline FIN & $-.0188(.0353)$ & $.1080(.1008)$ & $0038(.0346)$ & $-.0091(.0402)$ & $.0282(.0379)$ & $.0192(.0461)$ \\
\hline POLI & $.0323(.0296)$ & $-.0034(.0274)$ & $-.1913 * * *(.0729)$ & $.0491(.0409)$ & $.0432(.0414)$ & $-.2819 * * *(.0871)$ \\
\hline FDIL & $.3775 * * *(.1161)$ & $.3825^{* * *}(.1179)$ & $3769 * * *(.1133)$ & $.2881^{* *}(.1197)$ & $.2916^{* *}(.1217)$ & $.2856^{* *}(.1143)$ \\
\hline No. of obs & 307 & 307 & 307 & 310 & 310 & 310 \\
\hline F-Stat & 8.33 & 8.66 & 9.05 & 8.45 & 8.20 & 8.92 \\
\hline Prob $>F$ & .0000 & .0000 & .0000 & .0000 & .0000 & .0000 \\
\hline R-squared & .5882 & .5841 & .5950 & .5774 & .5722 & .5905 \\
\hline Root MSE & 1.899 & 1.909 & 1.883 & 1.978 & 1.990 & 1.948 \\
\hline
\end{tabular}

The ***, and *** indicate $10 \%, 5 \%$, and $1 \%$ significance levels, respectively. The standard errors are in the parentheses. All specifications also include the following control variables: corruption, financial risk index, political risk index, exports (\% of GDP), GDP growth rate, GDP per capita, GDP growth volatility, interest rate controls, lagged value of FDI net inflows, gross fixed capital formation, and inflation. Complete results are available from the authors upon request.

\section{References}

Abiad, A., \& Mody, A. (2005). Financial reform: What shakes it? What shapes it? American Economic Review, 95(1), 66-88.

Aitken, B., \& Harrison, A. (1999). Do domestic firms benefit from foreign investment? Evidence from Venezuela. American Economic Review, 89, 605-618.

Aizenman, J., \& Noy, I. (2003). Endogenous financial openness: Efficiency and political economy considerations (NBER Working Paper No. 10144).

Aizenman, J., \& Noy, I. (2006). FDI and trade: Two way linkages? Quarterly Review of Economics and Finance, 46(3), 317-337. 
Albuquerque, R., Loayza, N., \& Servén, L. (2005). World market integration through the lens of foreign direct investors. Journal of International Economics, 66(2), 267-295.

Alfaro, L., Chanda, A., Kalemli-Ozcan, S., \& Sayek, S. (2004). FDI and economic growth: The role of local financial markets. Journal of International Economics, 64(1), 89-112.

Arellano, M., \& Bond, S. (1991). Some tests of specification for panel data: Monte Carlo evidence and an application to employment equations. The Review of Economic Studies, 58, 277-297.

Asiedu, E., \& Lien, D. (2004). Capital controls and foreign direct investment. World Development, 32(3), 479-490.

Blonigen, B., \& Wang, M. G. (2005). Inappropriate pooling of wealthy and poor countries in empirical FDI studies. In T. H. Moran, E. M. Graham, \& M. Blomström (Eds.), Does foreign direct investment promote development? Washington, DC: Institute of International Economics Press.

Blonigen, B. (2005). A review of the empirical literature on FDI determinants (NBER Working Paper No. 11299).

Borensztein, E., de Gregorio, J., \& Lee, J. W. (1998). How does foreign direct investment affect economic growth? Journal of International Economics, 45, 115-135.

Carvalho, B. S., \& Garcia, M. (2006). Ineffective controls on capital inflows under sophisticated financial markets: Brazil in the nineties (NBER Working Paper No. 12283).

Chakrabarti, A. (2001). The determinants of foreign direct investment: Sensitivity analysis of cross-country regressions. Kyklos, 54(1), 89-114.

Chakrabarti, A. (2003). A theory of the spatial distribution of foreign direct investment. International Review of Economics and Finance, 12, 149-169.

Chinn, M., \& Ito, H. (2005). Notes on the calculation of the Chinn-Ito financial openness variable. Manuscript in preparation.

Chinn, M., \& Ito, H. (2006). What matters for financial development? Capital controls, institutions, and interactions. Journal of Development Economics, 81, 163-192.

Desai, M. A., Foley, F. C., \& Hines, J. R. (2004). Capital controls, liberalizations, and foreign direct investment (NBER Working Paper No. 10337).

Durham, B. (2004). Absorptive capacity and the effects of FDI and equity foreign portfolio investment on economic growth. European Economic Review, 48, 285-306.

Edison, H. J., Klein, M. W., Ricci, L. A., \& Sløk, T. (2004). Capital account liberalization and economic performance: Survey and synthesis. International Monetary Fund Staff Papers, 51(2), 220-256.

Edwards, S. (in press). Capital account openness and crises. Journal of International Money and Finance.

Edwards, S., \& Rigobon, R. (2005). Capital controls, exchange rate volatility and external vulnerability (NBER Working Paper No. 11434).

Fernández-Arias, E., \& Hausmann, R. (2001). Is foreign direct investment a safer form of financing? Emerging Markets Review, 2(1), 34-49.

Forbes, K. (2006). The microeconomic evidence on capital controls: No free lunch. In S. Edwards (Ed.), International capital flows. Chicago: Chicago University Press.

Gastanaga, V. M., Nugent, J. B., \& Pashamova, B. (1998). Host country reforms and FDI inflows: How much difference do they make? World Development, 26(7), 1299-1314.

Gray, P. H. (2004). Assessing the need for controls over inward direct investment in developing countries. Global Economy Journal, 4 (2).

Hanson, G. H. (2001). Should countries promote foreign direct investment? (G-24 Discussion Paper No. 9).

Henry, P. B. (2003). Capital account liberalization, the cost of capital, and economic growth. American Economic Review, 93(2), 91-96.

Hines, J. (1996). Altered states: Taxes and the location of foreign direct investment in America. American Economic Review, 86(5), 1076-1094.

Hsiao, C., \& Shen, Y. (2003). Foreign direct investment and economic growth: The importance of institutions and urbanization. Economic Development and Cultural Change, 51(4), 883-896.

International Monetary Fund. (2000). Foreign direct investment statistics: How countries measure FDI. Washington, DC: IMF Press.

Joyce, J., \& Noy, I. (2005). The IMF and capital account liberalization (Santa Cruz Center for International Economics Working Paper No. 05-25).

Kennedy, P. (2003). A guide to econometrics. Cambridge, MA: MIT Press.

$\mathrm{Li}, \mathrm{X} .$, \& Liu, X. (2005). Foreign direct investment and economic growth: An increasingly endogenous relationship. World Development, 33(3), 393-407.

Marshall, M. G., \& Jaggers, K. (2000). POLITY IV PROJECT_Political regime characteristics and transitions, $1800-$ 1999: Dataset users' manual. Mimeo, University of Maryland. 
Mody, A. (2004). Is FDI integrating the world economy? World Economy, 27(8), 1195-1222.

Mody, A., \& Murshid, A. P. (2002). Growing up with capital flows. Journal of International Economics, 65(1), $249-266$.

Montiel, P., \& Reinhart, C. (1999). Do capital controls and macroeconomic policies influence the volume and composition of capital flows? Evidence from the 1990s. Journal of International Money and Finance, 18, 619-635.

Mooij, R. A., \& Ederveen, E. (2003). Taxation and foreign direct investment: A synthesis of empirical research. International Tax and Public Finance, 10, 673-693.

Quinn, D. P. (2003). Capital account liberalization and financial globalization, 1890-1999: A synoptic view. International Journal of Finance and Economics, 8(3), 189-204.

Sarno, L., \& Taylor, M. (1999). Hot money, accounting labels and the permanence of capital flows to developing countries: An empirical investigation. Journal of Development Economics, 59(2), 337-364.

Shatz, H. (2000). The location of US multinational affiliates, PhD thesis, Harvard University.

$\mathrm{Vu}, \mathrm{T}$. B., Gangnes, B., \& Noy, I. (2007). Is foreign direct investment good for growth? Evidence from sectoral analysis of China and Vietnam. Manuscript in preparation, University of Hawai'i.

Wei, S. J. (2000). How taxing is corruption on international investors? Review of Economics and Statistics, 82(1), 1-13. 